\title{
Mentoring and Curriculum Development Model to Improve Quality of Non-Formal Education (NFE) in Banten Province
}

\author{
Sholeh Hidayat ${ }^{1}$, Yayat Ruhiat ${ }^{2}$, Syafrizal $^{3}$ \\ Non-formal education Department of Faculty of Teaching and Education of \\ Sultan Ageng Tirtayasa University \\ sholeh.hidayat@untirta.ac.id
}

\begin{abstract}
Non-formal Education (NFE) is an educational path outside the school system can be structured and tiered. NFE activities can serve to develop the potential of learners with an emphasis on the mastery of knowledge and functional skills and the development of professional attitude and personality. In studies created a model mentoring and curriculum development. In making the model and curriculum development using Participatory Action Research. NFE curriculum development carried out an analysis of social indicators and social change. Furthermore, the study of practical alternatives that lead to modifications or new models of learning.
\end{abstract}

Keywords - non-formal education, mentoring, development, curriculum, new model curriculum NFE

\section{INTRODUCTION}

Non-Formal Education (NFE) is an educational path outside the school system can be structured and tiered. Joesoef stated NFE is training or guidance in accordance with the age and needs of life, with the aim of developing a level of skills, attitudes and values that allow for it to be efficient and effective participants in a family environment, work environment and even the communities and countries [1]. NFE management includes life skills education, early childhood education, youth education, women's empowerment education, literacy education, vocational education and job training. In general, NFE is organized for citizens who require education outside the school system and directed in order to act as a substitute for, enhancer, or complement formal education in order to support lifelong education. NFE as a setting it acknowledges the importance and value of an informal climate in NFE activities [2]. NFE activities serve to develop the potential of learners with an emphasis on the mastery of knowledge and functional skills and the development of professional attitude and personality. This is consistent with the mission of the micro medium-term national education that is empowering individual learners and institutions. Education management implemented towards independent individuals who resilient and adaptive to change. According Mulyasa, the resulting individual is a man whose fear of God Almighty, the virtuous have the technological skills with proficiency in social life [3]. The number of people who need educational services to improve their competence, is an opportunity for the delivery of NFE. Therefore, NFE in each district and the city continues to experience growth. Total NFE in Banten province as much as 845 with the details: the course as many as 562 agencies and Community Learning Center (CLC) of 283 [4]. The number of PNF in Banten province hopes will increase human resources in the future. To achieve these expectations, the need to reform the process, so that the results can be appreciated NFE comparable to a formal education. In this case, it is necessary equalization and assistance to processes occurring in the NFE in line with expectations. To improve the quality of NFE in Banten province, done by providing assistance to the tutors as well as the assessment and development of curriculum based on national standards of education. The tutor NFE need to be equipped to develop a curriculum for the system established refers to the characteristics and the national education system. In this study, the model guidance to develop a curriculum in an effort to improve the quality of non-formal education. Mentoring relationships provide opportunities for youth to engage in a variety of social and recreational interactions with adults. Such activities may provide both welcome respite and enjoyable experiences for youth who typically must contend with disadvantages and difficult, circumstances [5]. Meanwhile, in developing the curriculum should provide opportunities and possibilities for implementers to make adjustments to environmental conditions, culture and life of the community and the target group [6].

\section{THE ASSISTANCE AND DEVELOPMENT}

In mentoring and curriculum development NFE in Banten involving tutors. In mentoring and curriculum development NFE uses Participatory Action Research (PAR). Participatory research is a research completed through the democratic interaction between the instructor to participant [7]. Model tutor assistance to improve the quality of education used in this study, shown in Figure 1. 


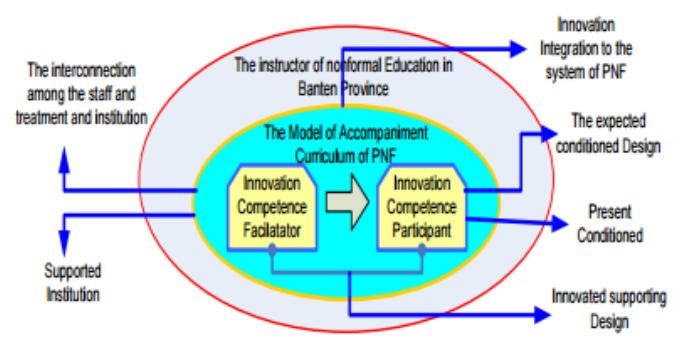

Fig. 1. The model of mentoring and curriculum development of NFE

Based on the picture above, during the mentoring process is integrated in the system NFE. In the process of the spread of competencies and innovation between facilitators, mapping, and created the group, resulting in the spread of the competence that leads to innovation. Based on the competence of institutional ties, the importance of the institutional support of the government of Banten Province. This mentoring models, have implications for participants' competence in making the design of the expected condition, and have innovated to develop in the present NFE. Mentoring requires "real-time" interactions, and although 21 st Century technologies may be used to support mentoring [8]. Furthermore, the personal relationship between the mentor and mentee and timely interventions are pivotal to the mentoring process [9]. In the process of the spread of competencies and innovation among facilitators who become instructors in these activities, mapping, and created the group, resulting in the spread of the competence that leads to innovation. In terms of facilitators who become instructors should be competent and get linkage between the manager and the unity of action in the institutional bond. Based on the institutional competence, it is expected that there will be institutional support from the government of Banten Province. This mentoring models have implications for participants' competence in making the design of the expected condition, and have innovated to develop in the present NFE. Teaching is an interpersonal, emotional and social profession. Similarly, mentoring requires "realtime" interactions, and although 21 st Century technologies may be used to support mentoring [10], the personal relationship between the mentor and mentee and timely interventions are pivotal to the mentoring process [11].

\section{DISCUSSION}

In designing the curriculum development of NFE conducted the investigation of the purpose of each institute for the competence of qualified graduates. Furthermore, the integration among materials, learning and evaluation must lead to competence, they were shown in Figure 2.

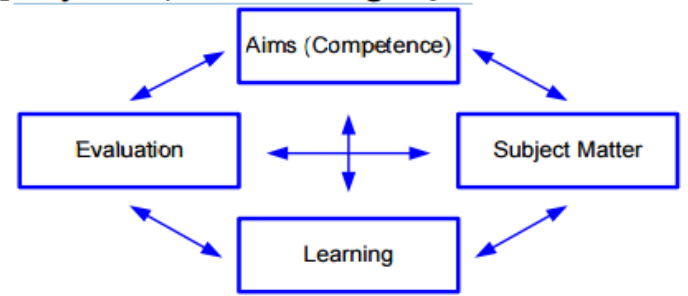

Fig. 2. Essential competition curriculum
Based on Figure 2 above, the facilitation of NFE curriculum facilitators and participants in an integrated analysis among the material and evaluation, and learning objectives. Between matter and learning are integrated analysis between the media and the methods used, so that the content submitted materials meet or exceed the standards of expected competence. Then, between learning and evaluation must meet the elements expected on competence and not be separated from learning. Furthermore, the evaluation and the destination cannot be separated from the expected material competence. In developing the curriculum of NFE conducted an analysis of social indicators and social change. From the social change, it get description of conditions and expectations of the expected quality of education. Furthermore, the study of practical alternatives lead to modifications or new models of learning. In the process of curriculum development, development of curriculum structure Thoman version Khun, more is shown in Figure 3.

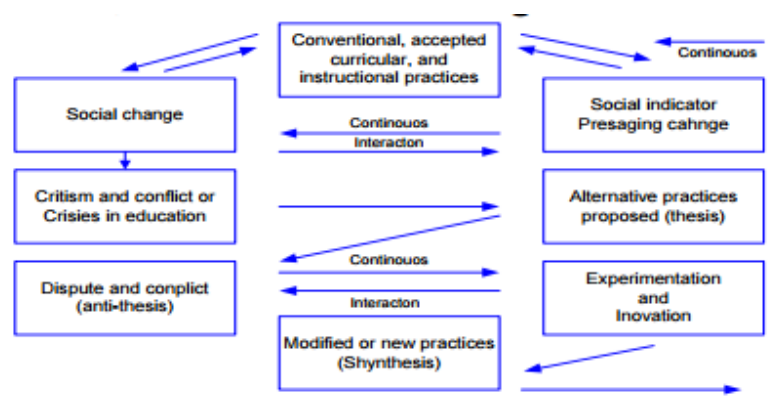

Fig. 3. Curriculum development

Based on Figure 3, the NFE curriculum development begins with the analysis of social indicators based on community needs in each district or city. Social indicators combined with social change, which studied continuously since the two interaction. From social change will be obtained NFE condition of good quality and function. Based on the results of the research paper, made some alternative options, so that there is synchronization between the expectations and needs of the people of the existence of NFE. With the expectations and needs, conducted experiments and innovation in order to obtain a modification even formed a new model of curriculum NFE in Banten Province. Results and development approach in line with the opinion, quoted from Jurgen Habernas stated that the process of education or educational praxis is a communicative action [6]. This means that educational praxis has a certain direction. The direction of the interactive action between learners with the world. Then, it is also in line with the opinion of Rogers, educators should plan the education that can meet the needs of the community.

\section{IV. . CONCLUSION}

NFE involves mentoring curriculum facilitators and participants, the model begins with an analysis carried out by the integration between the media and the methods used, so 
that the content of material that learned meet or exceed the standards of competence. Then, in curriculum development NFE begins with the analysis of social indicators based on community needs in each district / city. Social indicators form the basis for experimentation and innovation in order to obtain a modification even formed a new model of curriculum NFE in Banten Province

\section{REFERENCES}

[1] Joesoef, S. (1992). Konsep Dasar Pendidikan Non Formal. Jakarta: Bina Aksara.

[2] Kedrayate, A. (2012). Non-Formal Education: Is It Relevant or Obsolete. International Journal of Business, Humanities and Technology, Vol. 2 No. 4. 11-15.

[3] Mulyasa, E. (2013). Pengembangan dan Implementasi Kurikulum 2013. Bandung: Remaja Rosdakarya.

[4] Bastari. (2016, 2 Thues). PDSPK. Retrieved from Pusat Data Statistik Pendidikan dan Kebudayaan: http://www2.pdsp.kemdikbud.go.id /
[5] Rhodes, J., Spencer, R., Keller, T., Liang, B., \& Noam, G. (2006). A Model for the Influence of Mentoring Relationships on Youth Development. Journal of Community Psychology, Vol. 34, No. 6, 691707.

[6] Adharti, C. M., Listiyanti, M., Paresti, S., Wirantho, S. A., \& Santosa, B. (2012). Model Kurikulum Pemberdayaan Masyarakat Pesisir berbasis Ekonomi Produktif di Kabupaten Cirebon dan Kabupaten Jeneponto. Jakarta: Insentif Peningkatan Penelitian dan Perekayasa. Kementerianh Riset dan Teknologi.

[7] Fakih, M. (1990). Parcipatory Research on Popular Economic Development. Amherst: University of Massachusetts.

[8] Maxwell, T., Harrington, I., \& Smith, H. (2010). Supporting primary and secondary beginning teachers online. Australian Journal of teachers education, 42-58.

[9] Ganser, T. (1996). Preparing mentors of beginning teachers: An overview for staff developers. Journal of Staff Development 17(4), 8-11.

[10] Maxwell, T., Harrington, I., \& Smith, H. (2010). Supporting primary and secondary beginning teachers online. Australian Journal of teachers education, 42-58.

[11] Ganser, T. (1996). Preparing mentors of beginning teachers: An overview for staff developers. Journal of Staff Development 17(4), 8-11. 